\title{
Robust Counterpart Open Capacitated Vehicle Routing (RC-OCVRP) Model in Optimization of Garbage Transportation in District Sako and Sukarami, Palembang City
}

\author{
Fitri Maya Puspita1, Yusuf Hartono ${ }^{2}$, Nadia Zuliaty Syaputri ${ }^{3}$, Evi Yuliza ${ }^{4}$, Weni Dwi Pratiwi ${ }^{5}$ \\ 1,3,4,5 Department of Mathematics, Faculty of Mathematics and Natural Sciences, Sriwijaya University, Indonesia \\ ${ }^{2}$ Mathematics Study Program, Faculty of Education and Teacher Training, Sriwijaya University, Indonesia
}

\begin{tabular}{l} 
Article Info \\
\hline Article history: \\
Received May 9, 2018 \\
Revised Jul 9, 2018 \\
Accepted Jul 23, 2018 \\
\hline
\end{tabular}

Keyword:

Garbage transportation OCVRP

Optimization

Robust

\begin{abstract}
In this paper, the Robust Counterpart Open Capacitation Vehicle Rounting Problem (RC-OCVRP) Model has been established to optimize waste transport in districts Sako and districts Sukarami, Palembang City. This model is completed with the aid of LINGO 13.0 by using Branch and Bound solver to get the optimum route. For Sako districs, the routes are as follows: working area 1 is TPS 1-TPS 2-TPS 3-TPA with distance $53.39 \mathrm{~km}$, working area 2 is TPS 1-TPS 2-TPS 3-TPA with distance $48.14 \mathrm{~km}$, working area 3 is TPS 1-TPA with a distance of $22.98 \mathrm{~km}$, and working area 4 is TPS 1-TPS 2TPS 3-TPS 4-TPA with $45.45 \mathrm{~km}$ distance, and obtained the optimum route in Sukarami districts is as follows: working area 1 is TPS 1-TPS 2-TPA $44.39 \mathrm{~km}$, working area 2 is TPS 1-TPS 2-TPS 3-TPA with distance 49.32 $\mathrm{km}$, working area 3 is TPS 1-TPS 3-TPA-TPS 2-TPA with distance 58.57 $\mathrm{km}$, and working area 4 is TPS 1-TPA with a distance of $24.07 \mathrm{~km}$, working area 5 is TPS 1-TPS 3-TPA-TPS 2-TPS 4-TPA with a distance of $77.66 \mathrm{~km}$, and working area 6 is a TPS 1-TPS 2-TPS 3-TPA with a distante $44.94 \mathrm{~km}$.
\end{abstract}

Copyright $\odot 2018$ Institute of Advanced Engineering and Science. All rights reserved.

\section{Corresponding Author:}

Fitri Maya Puspita,

Department of Mathematics, Faculty of Mathematics and Natural Sciences, Sriwijaya University,

Jln. Raya Palembang-Prabumulih KM 32 Inderalaya, Ogan Ilir, Indonesia.

Email: fitrimayapuspita@unsri.ac.id

\section{INTRODUCTION}

Palembang city as a metropolitan city is facing a problem like other big cities, namely garbage. Almost $80 \%$ of the waste is from household waste. Garbage accumulation will have negative effects both for the environment and for human life. Several factors that cause the build up of garbage, one of which is the technique of transporting waste is that are not efficient. Therefore, to prevent the accumulation of waste, more accurate and efficient waste transport methods are needed to transport waste from the Temporary Disposal Site called TPS to landfills called TPA.

There are two types of garbage car used, namely amroll and dump truck. While there are three types of waste containers in the TPS, the container with a capacity of $4 \mathrm{~kg}$, garbage containers made of fiber with a capacity of $3.8 \mathrm{~kg}$, and a waste bin made of concrete with a capacity of $5 \mathrm{~kg}$. According to [1] transportation of waste from TPS to TPA is done based on the division of working area.

An application of Vehicle Routing Problem (VRP) is a matter of delivery and retrieval of goods. Meanwhile, according to [2], VRP applications appear in design and distribution systems whose operations are determined by route construction, and the goal is to minimize total cost and travel routes. If the vehicle has a single capacity with a single commodity then it is called a Capacitated Vehicle Routing Problem (CVRP). Applications related to shipping, such as consumer products and garbage collection and transportation including air, rail, ships and motor vehicles [3]. In networks, routing problems are also critical issues to be discussed. In some cases,routing problem wireless sensor network [4] and improved Augmented 
Line Segment Based (ALSB) for steiner minimum treeis currently discussed. On the issue of Capacitated Vehicle Routing Problem (CVRP) as discussed in [5], [6], the carrier vehicle must return to the depot after completing its work. However, for some vehicle route problems such as the route of the garbage transport vehicle, the above-mentioned conditions cannot be performed. This becomes inefficient, as it will cost more travel and more time wasted. This is what the authors found happening in the field, that the garbage car does not return to the depot to raise the house of each driver. This becomes a new problem because the path formed turns into an open path. Thus, the CVRP problem becomes an Open Capacitated Vehicle Routing Problem (OCVRP) problem as quoted from [7].

Robustness in modelling occurs in some environments. For instance, robustness can occur in dynamical power system [8], robust performance in system operation of an aircraft [9] or even robust model predictive controller (RMPC) for adaptive system [10]. The Robust Counterpart (RC) method in this case was developed by Ben-Tal and Nemirovski in early 1997. In this methodology, RC represents the worst-case oriented approach, a solution called robust feasible methods [11]. The emergence of robust as a methodology is considered capable of resolving the uncertainty of existing data [12]. In the garbage haul, the uncertainty of the data on the garbage volume in each TPS is found. Based on the facts that arise, then the problem is classified as a Demand Robust Counterpart (DRC) problem. DRC issues can be solved by MILP with the help of Lingo 13.0 Program and solved with Branch and Bound solver.

Sako and Sukarami Districts are one of the densely populated districts of Palembang. This research is based on research on 16 districts in Palembang City. To obtain a minimum route with maximum waste capacity, use Robust Counterpart Open Capacitated Vehicle Routing Problem (RC-OCVRP) method. The specialty of the RC-OCVRP method is to get the optimum route according to the circumstances that occur in the field that the garbage truck does not return to the depot but to the home of each driver as well as the uncertainty of the volume of garbage. The objective of this research is to apply Robust Counterpart Open Capacitated Vehicle Routing Problem (RC-OCVRP) method to optimize waste transportation route based on distance and volume of TPS in Sako and Sukarami districts, Palembang City.

\section{RESEARCH METHOD}

The writing of this research is a case study, using data of garbage transportation in two Districts in Palembang City, Sako and Sukarami Subdistricts. Data obtained from DKK Kota Palembang and field survey in the form of direct interview with DKK driver and measurement of distance between TPS and TPS to TPA. The steps taken are:

a. Collecting data in the form of: the number of cars operating in the districts of Sako and districts Sukarami along with the volume of car capacity, the route through each car and the volume transported from each TPS, the distance traveled from the TPS to the TPS to the TPA.

b. Determining Distance Matrix.

c. Model the data into Robust Counterpart Model.

d. Establish Models by determining working area in each districts in OCVRP and CVRP issues.

e. Apply the model of each working area into Lingo 13.0.

f. Looking for optimal integer solution from non-optimal integer solution by using Branch and bound solver method on LINGO 13.0.

g. Determining the optimal route on working area for the case of garbage transportation by Branch and Bound solver method on LINGO 13.0.

\section{RESULTS AND ANALYSIS}

DKK Palembang City provides 4 garbage transport vehicles in Sako districts and 6 garbage transport vehicles in districts Sukarami with a carrying capacity of up to 8 tons. Each garbage transport vehicle is divided into individual working area. This model consists of a combination of Robust Counterpart Model and OCVRP Model.

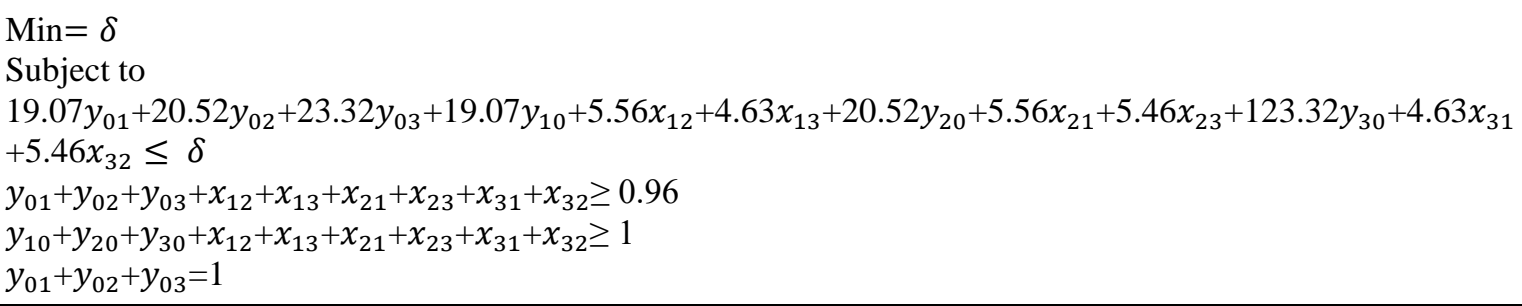


$2800 \leq l_{1}<8000$

$2800 \leq l_{2}<8000$

$2100 \leq l_{3}<8000$

$l_{1}-l_{2}+8000 x_{12} \leq 5200$

$l_{1}-l_{3}+8000 x_{13} \leq 5900$

$l_{2}-l_{1}+8000 x_{21} \leq 5200$

$l_{2}-l_{3}+8000 x_{23} \leq 5900$

$l_{3}-l_{1}+8000 x_{31} \leq 5200$

$l_{3}-l_{2}+8000 x_{32} \leq 5200$

$\delta, y_{01}, y_{02}, y_{03}, x_{12}, x_{13}, x_{21}, x_{23}, x_{31}, x_{32} \geq 0$

Table 1 is a solution table of the Robust Counterpart OCVRP model in Sako districts. From the table, it can be obtained that the optimal route distance for working area 1 is $53.39 \mathrm{~km}$, working area 2 is $48.14 \mathrm{~km}$, working area 3 is $22.98 \mathrm{~km}$, and working area 4 is $45.45 \mathrm{~km}$. Whereas Table 2 shows the value of the decision variable for working area 1, Table 3 shows the value of the decision variable for working area 2 , Table 4 shows the value of the decision variable for working area 3 , and Table 5 shows the value of the decision variable for working area 4.

Table 1. Solutionof Robust Counterpart OCVRP in Sako District

\begin{tabular}{ccccc}
\hline Solver Status & Working Area 1 & Working Area 2 & Working Area 3 & Working Area 4 \\
\hline Model Class & MILP & MILP & MILP & MILP \\
State & Global Optimal & Global Optimal & Global Optimal & Global Optimal \\
Objective & 53.39 & 48.14 & 22.98 & 45.45 \\
Infeasibelity & 0 & 0 & 0 & 0 \\
Iterations & 0 & 0 & 0 & 0 \\
Solver Type & Branch and Bound & Branch and Bound & Branch and Bound & Branch and Bound \\
Best Objective & 53.39 & 48.14 & 22.98 & 45.45 \\
Steps & 0 & 0 & 0 & 0 \\
Update Interval & 2 & 2 & 2 & 2 \\
GMU & 25 & 25 & 19 & 30 \\
ER & 0 & 0 & 0 & 0 \\
\hline
\end{tabular}

Table 2. Robust Variable Value with OCVRP Working Area 1 in Sako District

\begin{tabular}{cccc}
\hline Variable & Working Area 1 & Variable & Working Area 1 \\
\hline$\delta$ & 53.39 & $x_{21}$ & 0 \\
$y_{01}$ & 0 & $x_{23}$ & 1 \\
$y_{02}$ & 0 & $y_{30}$ & 1 \\
$y_{03}$ & 0 & $x_{31}$ & 0 \\
$y_{10}$ & 0 & $x_{32}$ & 0 \\
$x_{12}$ & 1 & $l_{1}$ & 2800 \\
$x_{13}$ & 0 & $l_{2}$ & 5600 \\
$y_{20}$ & 0 & $l_{3}$ & 7700 \\
\hline
\end{tabular}

The values listed in $l_{1}, l_{2}, l_{3}$ of Table 2 represent the vlome of waste transported upon leaving TPS$i(i=1,2,3)$, so that $l_{1}=2800, l_{2}=5600, l_{3}=7700$. A route that must be passed by dump truck for garbage transport at working area 1 is TPS 1-TPS 2-TPS 3-TPA Karya Jaya. Minimum route the driver passes in graph form is explained in Figure 1.

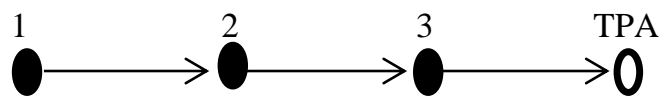

Figure 1. Vehicle route of working area 1 Sako in District

The values listed in $l_{1}, l_{2}, l_{3}$ of Table 3 represent the vlome of waste transported upon leaving TPS$i(i=1,2,3)$, so that $l_{1}=2700, l_{2}=5600, l_{3}=7800$. Routes that must be passed by dump truck for garbage transport at working area 2 is TPS 1-TPS 2-TPS 3-TPA Karya Jaya. Minimum route the driver passes is depecited in Figure 2. 
Table 3. Robust Variable Value with OCVRP Working Area 2 in Sako District

\begin{tabular}{cccc}
\hline Variable & Working Area 2 & Variable & Working Area 2 \\
\hline$\delta$ & 48.14 & $x_{21}$ & 0 \\
$y_{01}$ & 0 & $x_{23}$ & 1 \\
$y_{02}$ & 0 & $y_{30}$ & 1 \\
$y_{03}$ & 0 & $x_{31}$ & 0 \\
$y_{10}$ & 0 & $x_{32}$ & 0 \\
$x_{12}$ & 1 & $l_{1}$ & 2700 \\
$x_{13}$ & 0 & $l_{2}$ & 5600 \\
$y_{20}$ & 0 & $l_{3}$ & 7800 \\
\hline
\end{tabular}

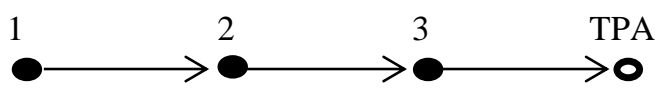

Figure 2. Vehicle route of working area 2 in Sako District

Table 4. Robust Variable Value with OCVRP Working Area 3 in Sako districts

\begin{tabular}{cc}
\hline Variable & Working Area 3 \\
\hline$\delta$ & 22.98 \\
$y_{01}$ & 0 \\
$y_{10}$ & 1 \\
$l_{1}$ & 0 \\
$l_{2}$ & 7500 \\
\hline
\end{tabular}

The values listed in $l_{1}, l_{2}$ of Table 4 represent the vlome of waste transported upon leaving TPS$i(i=1,2)$, so that $l_{1}=0, l_{2}=7500$. Routes that must be passed by dump truck for garbage transport at working area 3 is TPS 1-TPA Karya Jaya. Minimum route the driver passes in graph form as explained in Figure 3.

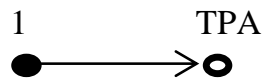

Figure 3. Vehicle route of working area 3 in Sako districts

Table 5. Robust Variable Value with OCVRP Working Area 4 in Sako districts

\begin{tabular}{cccc}
\hline Variable & Working Area 4 & Variable & Working Area 4 \\
\hline$\delta$ & 45.45 & $y_{30}$ & 0 \\
$y_{01}$ & 0 & $x_{31}$ & 0 \\
$y_{02}$ & 0 & $x_{32}$ & 0 \\
$y_{03}$ & 0 & $x_{34}$ & 1 \\
$y_{04}$ & 0 & $y_{40}$ & 1 \\
$y_{10}$ & 0 & $x_{41}$ & 0 \\
$x_{12}$ & 1 & $x_{42}$ & 0 \\
$x_{13}$ & 0 & $x_{43}$ & 0 \\
$x_{14}$ & 0 & $l_{1}$ & 1800 \\
$y_{20}$ & 0 & $l_{2}$ & 4500 \\
$x_{21}$ & 0 & $l_{3}$ & 6000 \\
$x_{23}$ & 1 & $l_{4}$ & 7600 \\
$x_{24}$ & 0 & & \\
\hline
\end{tabular}

The values listed in $l_{1}, l_{2}, l_{3}, l_{4}$ of Table 5 . The values listed in TPS- $i(i=1,2,3,4)$, so that $l_{1}=$ $1800, l_{2}=4500, l_{3}=6000, l_{4}=7600$. Routes that must be passed by dump truck for garbage transport at working area 4 is TPS 1-TPS 2 -TPS 3-TPS 4-TPA Karya Jaya. Minimum route the driver passes is depicted in Figure 4.

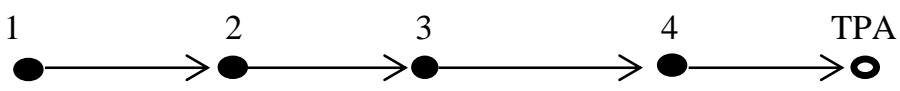

Figure 4. Vehicle route of working area 4 in Sako districts 
Table 6 is a solution table of the Robust Counterpart OCVRP model in Sukarami districts. From the table, it can be found that the optimal route distance for working area 1 is $44.39 \mathrm{~km}$, working area 2 is 49.32 $\mathrm{km}$, working area 3 is $58.57 \mathrm{~km}$, working area 4 is $24.07 \mathrm{~km}$, working area 5 is $77.66 \mathrm{~km}$. And working area 6 is $44.94 \mathrm{~km}$. While Table 7 shows the value of the decision variable for working area 1, Table 8 shows the value of the decision variable for working area 2, Table 9 shows the value of the decision variable for working area 3, Table 10 shows the value of the decision variable for working area 4, Table 11 shows the value of the decision variable for working area 5, and Table 12 shows the value of the decision variable for working area 6 . The values listed in $l_{1}, l_{2}$ of Table 7 represent the vlome of waste transported upon leaving TPS- $i(i=1,2)$, so that $l_{1}=3800, l_{2}=7500$. Routes that must be passed by dump truck for garbage transport at working area 1 is TPS 1-TPS 2-TPS 3-TPA Karya Jaya. Minimum route the driver passes in Figure 5.

Table 6. Solution of Robust Counterpart OCVRP in Sukarami districts

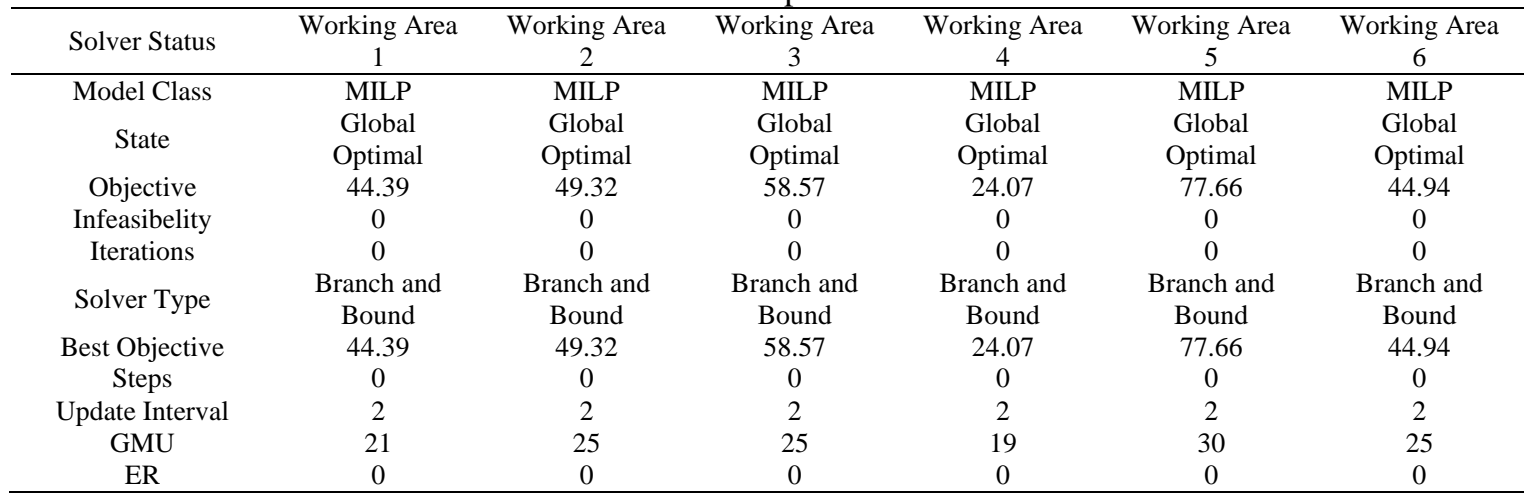

Table 7. Robust Variable Value with OCVRP Working Area 1 in Sukarami districts

\begin{tabular}{cccc}
\hline Variable & Working Area 1 & Variable & Working Area 1 \\
\hline$\delta$ & 44.39 & $y_{20}$ & 1 \\
$y_{01}$ & 0 & $x_{21}$ & 0 \\
$y_{02}$ & 0 & $l_{1}$ & 3800 \\
$y_{10}$ & 0 & $l_{2}$ & 7500 \\
$x_{12}$ & 1 & & \\
\hline
\end{tabular}

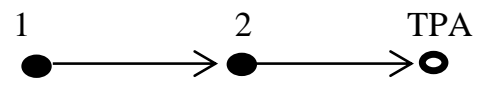

Figure 5. Vehicle route of working area 1in Sukarami districts

Table 8. Robust Variable Value with OCVRP Working Area 2 in Sukarami districts

\begin{tabular}{cccc}
\hline Variable & Working Area 2 & Variable & Working Area 2 \\
\hline$\delta$ & 49.32 & $x_{21}$ & 0 \\
$y_{01}$ & 0 & $x_{23}$ & 1 \\
$y_{02}$ & 0 & $y_{30}$ & 1 \\
$y_{03}$ & 0 & $x_{31}$ & 0 \\
$y_{10}$ & 0 & $x_{32}$ & 0 \\
$x_{12}$ & 1 & $l_{1}$ & 2500 \\
$x_{13}$ & 0 & $l_{2}$ & 5100 \\
$y_{20}$ & 0 & $l_{3}$ & 7800 \\
\hline
\end{tabular}

The values listed in $l_{1}, l_{2}, l_{3}$ of Table 8 represent the vlome of waste transported upon leaving TPS$i(i=1,2,3)$, so that $l_{1}=2500, l_{2}=5100, l_{3}=7800$. Routes that must be passed by dump truck for garbage transport at working area 2 is TPS 1-TPS 2-TPS 3-TPA Karya Jaya. Minimum route the driver passes is explained in Figure 6. 


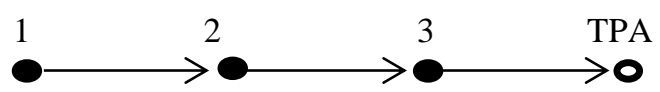

Figure 6. Vehicle route of working area 2 in Sukarami districts

Table 9. Robust Variable Value with OCVRP Working Area 3 in Sukarami districts

\begin{tabular}{cccc}
\hline Variable & Working Area 3 & Variable & Working Area 3 \\
\hline$\delta$ & 58.57 & $x_{21}$ & 0 \\
$y_{01}$ & 0 & $x_{23}$ & 0 \\
$y_{02}$ & 0 & $y_{30}$ & 1 \\
$y_{03}$ & 1 & $x_{31}$ & 0 \\
$y_{10}$ & 0 & $x_{32}$ & 0 \\
$x_{12}$ & 1 & $l_{1}$ & 3600 \\
$x_{13}$ & 0 & $l_{2}$ & 7700 \\
$y_{20}$ & 1 & $l_{3}$ & 6700 \\
\hline
\end{tabular}

The values listed in $l_{1}, l_{2}, l_{3}$ of Table 9 represent the vlome of waste transported upon leaving TPS$i(i=1,2,3)$, so that $l_{1}=3600, l_{2}=7700, l_{3}=6700$. Routes that must be passed by dump truck for garbage transport at working area 3 is TPS 1-TPS 2- TPA Karya Jaya-TPS 3-TPA Karya Jaya. Minimum route is in Figure 7.

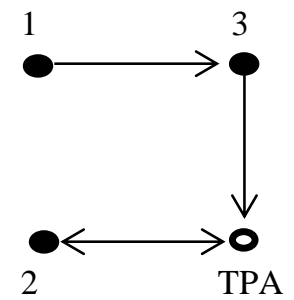

Figure 7. Vehicle route of working area 3 in Sukarami districts

Table 10. Robust Variable Value with OCVRP Working Area 4 in Sukarami districts

\begin{tabular}{cc}
\hline Variable & Working Area 4 \\
\hline$\delta$ & 24.07 \\
$y_{01}$ & 0 \\
$y_{10}$ & 1 \\
$l_{1}$ & 0 \\
$l_{2}$ & 7600 \\
\hline
\end{tabular}

The values listed in $l_{1}, l_{2}$ of Table 10 represent the vlome of waste transported upon leaving TPS$i(i=1,2)$, so that $l_{1}=0, l_{2}=7600$. Routes that must be passed by dump truck for garbage transport at working area 4 is TPS 1-TPA Karya Jaya. Minimum route the driver passes in graph form as Figure 11 explained.

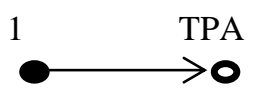

Figure 8. Vehicle Route of Working Area 4 in Sukarami districts

The values listed in $l_{1}, l_{2}, l_{3}, l_{4}$ of Table 11 . The values listed in TPS- $i(i=1,2,3,4)$, so that $l_{1}=$ $4900, l_{2}=3800, l_{3}=7900, l_{4}=7400$. Routes that must be passed by dump truck for garbage transport at working area 5 is TPS 1-TPS 3 -TPA Karya Jaya-TPS 2-TPS 4-TPA Karya Jaya. Minimum route the driver passes is described in Figure 9. 
Table 11. Robust Variable Value with OCVRP Working Area 5 in Sukarami districts

\begin{tabular}{cccc}
\hline Variable & Working Area 5 & Variable & Working Area 5 \\
\hline$\delta$ & 77.66 & $y_{30}$ & 1 \\
$y_{01}$ & 0 & $x_{31}$ & 0 \\
$y_{02}$ & 1 & $x_{32}$ & 0 \\
$y_{03}$ & 0 & $x_{34}$ & 0 \\
$y_{04}$ & 0 & $y_{40}$ & 1 \\
$y_{10}$ & 0 & $x_{41}$ & 0 \\
$x_{12}$ & 0 & $x_{42}$ & 0 \\
$x_{13}$ & 1 & $x_{43}$ & 0 \\
$x_{14}$ & 0 & $l_{1}$ & 4900 \\
$y_{20}$ & 0 & $l_{2}$ & 3800 \\
$x_{21}$ & 0 & $l_{3}$ & 7900 \\
$x_{23}$ & 0 & $l_{4}$ & 7400 \\
\hline
\end{tabular}

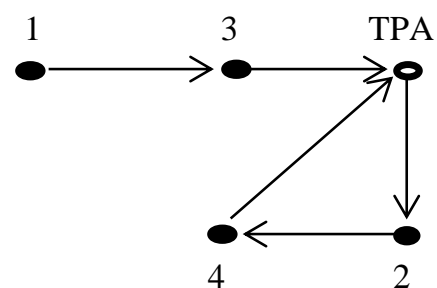

Figure 9. Vehicle Route of Working Area 5 in Sukarami districts

Table 12. Robust Variable Value with OCVRP Working Area 6 in Sukarami districts

\begin{tabular}{cccc}
\hline Variable & Working Area VI & Variable & Working Area VI \\
\hline$\delta$ & 44.94 & $x_{21}$ & 0 \\
$y_{01}$ & 0 & $x_{23}$ & 1 \\
$y_{02}$ & 0 & $y_{30}$ & 1 \\
$y_{03}$ & 0 & $x_{31}$ & 0 \\
$y_{10}$ & 0 & $x_{32}$ & 0 \\
$x_{12}$ & 1 & $l_{1}$ & 2500 \\
$x_{13}$ & 0 & $l_{2}$ & 5600 \\
$y_{20}$ & 0 & $l_{3}$ & 7900 \\
\hline
\end{tabular}

The values listed in $l_{1}, l_{2}, l_{3}$ of Table 12 represent the vlome of waste transported upon leaving TPS$i(i=1,2,3)$, so that $l_{1}=2500, l_{2}=5600, l_{3}=7900$. Routes that must be passed by dump truck for garbage transport at working area 6 is TPS 1-TPS 2-TPS 3-TPA Karya Jaya. Minimum route the driver passes in graph form as Figure 10 explained.

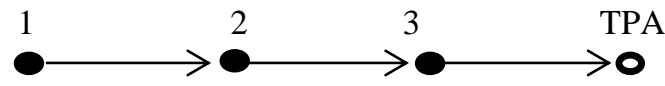

Figure 10. Vehicle route of working area 6 in Sukarami districts

\section{CONCLUSION}

From the calculation of Robust Counterpart OCVRP Model with the help of Lingo 13.0 Program, it can be obtained the optimum route in Sako districts is as follows. For working area 1, the route is TPS 1-TPS 2-TPS 3-TPA with distance of $53.39 \mathrm{~km}$. For working area 2, the route is TPS 1-TPS 2-TPS 3-TPA with distance of $48.14 \mathrm{~km}$. Whereas for working area 3, the route is TPS 1-TPA with a distance of $22.98 \mathrm{~km}$, and working area 4, the route is TPS 1-TPS 2-TPS 3-TPS 4-TPA with $45.45 \mathrm{~km}$ distance. Next, for the obtained optimum route in Sukarami districts is as follows.For working area 1, the routeis TPS 1-TPS 2-TPA of 44.39 $\mathrm{km}$. For working area 2, the route is TPS 1-TPS 2-TPS 3-TPA with distance of $49.32 \mathrm{~km}$. For working area 3 , the route is TPS 1-TPS 3-TPA-TPS 2-TPA with distance $58.57 \mathrm{~km}$.Lastly, for working area 4, the route is TPS 1-TPA with a distance of $24.07 \mathrm{~km}$. Working area 5 has route of TPS 1-TPS 3-TPA-TPS 2-TPS 4-TPA with a distance of $77.66 \mathrm{~km}$, and working area 6 is a TPS 1-TPS 2-TPS 3-TPA with a distante $44.94 \mathrm{~km}$. 


\section{ACKNOWLEDGEMENTS}

The research leading to this study was financially supported by Sriwijaya University for support through Competitive Leading Grant in 2017.

\section{REFERENCES}

[1] Irmeilyana, F.M. Puspita, and Indrawati, Pemodelan dan solusi optimal Open Capacitated Vehicle Routing Problem pada transportasi pengangkutan sampah di District Ilir Timur I Kota Palembang, in Proceeding Konferensi Nasional Teknologi Informasi dan Aplikasinya, Fak. Ilmu Komputer UNSRI. 2009.

[2] P. Toth, and D. Vigo, Exact solution of the vehicle routing problem, in Fleet Management and Logistics, T.G. Cranic and G. Laporte, Editors. 1998, Kluwer Academic Publisher: Norwell. p. 1-31.

[3] J. Sniezek, and L. Bodin, 'Cost models for vehicle routing problems, in 35th Hawaii International Conference on System Science. 2002. Hawaii.

[4] S. Umar, P.V.R.D.P. Rao, and S. Gutta, Tree Based Energy Balancing Routing Protocol by Self Organizing in Wireless Sensor Networks, International Journal of Electrical and Computer Engineering (IJECE), 2015. 5(6): p. 1486-1491.

[5] F.M. Puspita, On Capacitated Vehicle Routing Problem, in Mathematics Department. 2004, M.Sc Thesis. Curtin University of Technology: Perth.

[6] F.M. Puspita, Aplikasi Teknik Preprocessing pada PBILP dan Solusinya dengan Branch and bound. JMAP, 2006. 5(2): p. 127-132.

[7] A.N. Letchford, J. Lysgaard., and R.W. Eglese. A branch and cut algorithm for capacitated open vehicle routing problem. 2006 [cited 200911 July]; Available from: http://www.lancs.ac.uk/staff/letchfoa/articles/ovrp/pdf.

[8] H.M. Soliman, and M. Soliman, Design of Observer-Based Robust Power System Stabilizers. International Journal of Electrical and Computer Engineering (IJECE), 2016. 6(5): p. 1956-1966.

[9] J.M. Fard, M.A. Nekoui, A.K. Sedigh and R.Amjadifard, Robust Multivariable Controller Design with the simultaneous $\mathrm{H} 2 / \mathrm{H} \infty / \mu$ for a Single Person Aircraft. International Journal of Electrical and Computer Engineering (IJECE), 2013. 3(2): p. 279-286.

[10] F. Pirouzmand, Robust Model Predictive Control Based on MRAS for Satellite Attitude Control System. International Journal of Electrical and Computer Engineering (IJECE), 2014. 4(1): p. 81-92.

[11] Y. Nesterov, and A. Nemirovski, Interior Point Polynomial Algorithms in Convex Programming. SIAM Studies in Apllied Mathematics, 1994.

[12] A. Ben-Tal, and A. Nemirovski, Lectures on Modern Convex Optimization: Analysis, Algorithms, and Engineering Applications. 2001: Society for Industrial and Applied Mathematics.

\section{BIOGRAPHIES OF AUTHORS}

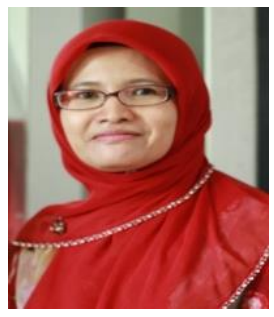

Fitri Maya Puspita received her S.Si degree in Mathematics from Sriwijaya University, South Sumatera, Indonesia in 1997. Then she received her M.Sc in Mathematics from Curtin University of Technology (CUT) Western Australia in 2004. She reveived his Ph.D in Science and Technology in 2015 from Universiti Sains Islam Malaysia. She has been a Mathematics Department member at Faculty mathematics and Natural Sciences Sriwijaya University South Sumatera Indonesia since 1998. Her research interests include optimization and its applications such as vehicle routing problems and QoS pricing and charging in third generation internet.

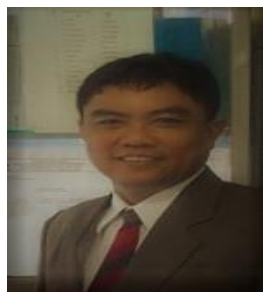

Yusuf Hartono received his Bachelor of Science in Mathematics Education from Sriwjaya University, Indonesia in 1988. Then he received his M.Sc in Math and Stats from Univ. of Missouri at Rolla, USA in 1993. He reveived his Ph.D in Mathematics in 2003 from Technische Universiteit Delft, Nederland. He has been a Mathematics Study Program member at Faculty of Education and Theacher Training Sriwijaya University South Sumatera Indonesia since 1990.His research interests include statistics and its application.

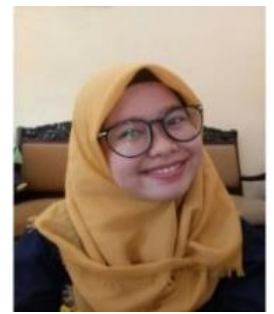

Nadia Zuliaty Syaputri currently is an undergraduate student at Mathematics Department, Faculty of Mathematics and Natural Sciences, Sriwijaya University. She is currently on final stage of her thesis submission. Her topic interest includes Optimization and its application on routing some commodities. 


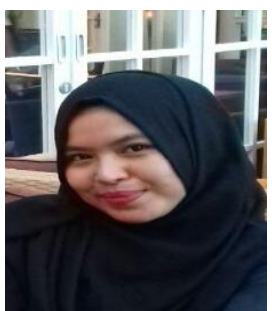

Weni Dwi Pratiwi received her S.Pd degree in Mathematics Education from Sriwijaya University, South Sumatera, Indonesia in 2011. Then she also received her M.Sc in Mathematics Education from Sriwijaya University, South Sumatera, Indonesia in 2013 and from Utrecht University, Netherlands. She has been a Mathematics Education Study Program member at Faculty of Education and Teacher Training Sriwijaya University South Sumatera Indonesia since 2015. Her research interests include mathematics education and its applications.

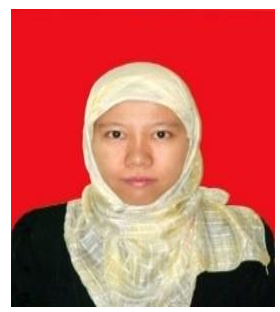

Evi Yuliza her S.Si degree in Mathematics from Sriwijaya University, South Sumatera, Indonesia in 2000. Then she received her M.Si in Mathematics from Gadjah Mada University in 2004. Her research interests includse Algebra. She has been a Mathematics Department member at Faculty mathematics and Natural Sciences Sriwijaya University South Sumatera Indonesia since 2008 . 